\title{
Popular Fiction and Social Change
}




\section{Popular Fiction and Social Change}

EDITED BY

CHRISTOPHER PAWLING

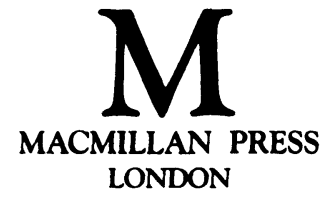


(C) Rosalind Brunt, Bridget Fowler, David Glover, Jerry Palmer, Martin Jordin, Stuart Laing, Adrian Mellor, Christopher Pawling 1984

Softcover reprint of the hardcover 1st edition 1984 978-0-333-34319-7

All rights reserved. No part of this publication may be reproduced or transmitted, in any form or by any means, without permission

First published 1984 by

THE MACMILLAN PRESS LTD

London and Basingstoke

Companies and representatives

throughout the world

Typeset by

Wessex Typesetters Ltd

Frome, Somerset

British Library Cataloguing in Publication Data

Pawling, Christopher

Popular fiction and social change.

1. Popular fiction - England - History

I. Title

$820.9 \quad$ PR149.P6

ISBN 978-0-333-34320-3 ISBN 978-1-349-15856-0 (eBook)

DOI 10.1007/978-1-349-15856-0 


\section{Contents}

Notes on Contributors vi

Introduction: Popular Fiction: Ideology or Utopia?

CHRISTOPHER PAWLING

1 Science Fiction and the Crisis of the

Educated Middle Class

ADRIAN MELLOR

2 Contemporary Futures: The Analysis of Science Fiction

MARTIN JOR DIN

3 Thrillers

JERRY PALMER

4 True to Me Always: An Analysis of Women's Magazine Fiction

BRIDGET FOWLER

5 A Career in Love: The Romantic World of Barbara Cartland ROSALIND BRUNT

6 Room at the Top: The Morality of Affluence STUART LAING

7 Utopia and Fantasy in the Late 1960s:

Burroughs, Moorcock, Tolkien

DAVID GLOVER

8 Watership Down: Rolling Back the 1960s

CHRISTOPHER PAWLING

Further Reading 


\section{Notes on Contributors}

ROSALIND BRUNT is a senior lecturer in the department of Communication Studies at Sheffield City Polytechnic, where she specialises in the fields of mass communications and women's studies. She has co-edited, with George Bridges, Silver Linings: Some Strategies for the Eighties and, with Caroline Rowan, Feminism, Culture and Politics.

BRIDGET FOWLER lectures in sociology at the University of Glasgow, where her teaching includes a course on the sociology of literature. The chapter which she has contributed to this volume is a revised version of an article which first appeared in the British Journal of Sociology in March 1979.

DAve glover is a senior lecturer in the School of Applied Social Studies at Humberside College of Higher Education, where his teaching includes courses on mass communications. He is the author of a number of articles in the field of cultural studies and of The Sociology of the Mass Media.

MARTIN JORDIN is a senior lecturer in the department of Communication Studies at Sheffield City Polytechnic where he specialises in the sociology of literature. His research has concentrated on the relationship between the arts and the state.

STUART LAING lectures in English in the School of Cultural and Community Studies at the University of Sussex. He has published articles on pre-war literature, including one on the popular novelist, Philip Gibbs, in Literature and History, and has just completed a number of pieces on the post-war novel and the conditions of literary production for a forthcoming volume on the period $1945-70$.

ADRIAN MELLOR is a senior lecturer at Liverpool Polytechnic, where his teaching includes a course on the sociology of literature. His publications include a chapter on 'Writers and the General Strike' (with C. Pawling and C. Sparks) in M. Morris (ed.) The General Strike and several essays in the Student Encyclopedia of Sociology, edited by Michael Mann.

JERRY PALMER lectures on sociology and cultural studies at the City Polytechnic in London. His publications include an essay 'Thrillers: The Deviant Behind the Consensus' in The Politics of Deviance, I. Taylor and L. Taylor (eds) and Thrillers: Genesis and Structure of a Popular Genre. 
CHRISTOPHER PAWLING is a senior lecturer in the department of Communication Studies at Sheffield City Polytechnic where he teaches courses on the sociology of literature. His publications include 'Writers and the General Strike' (with Adrian Mellor) and an article on George Orwell and the Documentary in Literature and History. 